\title{
Sir A. Landsborough Thomson CB DSC 1890-1977
}

Landsborough Thomson, who died on June 9, had been a Vice-President of FPS since 1963. Son of the distinguished Scottish zoologist, Professor J. Arthur Thomson, he was a man of many parts in the natural history and conservation world. Professionally a most able medical research administrator, he filled many other roles out of office hours, among them President of the Zoological Society of London, Chairman of the Trustees of the British Museum (Natural History), President of the British Ornithologists' Union, Chairman of the British Trust for Ornithology, and Chairman of the Council for Nature.

For the Fauna Preservation Society, he served regularly as a Council Member from 1958 and from 1963 as a Vice-President. A quiet man with a nice sense of humour, always available with wise advice, his main contribution to the Society's work was to assist the late W. H. Pearsall in his path-breaking report on the Serengeti Plains ecosystem, commissioned and financed by the FPS, which led directly to the creation of the Serengeti National Park and the Ngorongoro Conservation Area. Landsborough was a distinguished ornithologist and a recognised authority on migration, and he is likely to be remembered for many years as the polymathic editor of $A$ New Dictionary of Birds on behalf of the BOU, in which he was assisted by his wife Maisie, a monumental work and one which could hardly be bettered as his memorial. RICHARD FITTER

\section{David Sheldrick}

David Sheldrick, for many years Warden of Kenya's Tsavo East National Park, died in June. He had already left East Tsavo and early in the year accepted the job of coordinating the development of the protected areas throughout Kenya. This was at some personal sacrifice, says one of his Kenyan friends, but he took it as a challenge.

Sir Frank Fraser Darling writes of him:

'David Sheldrick is dead, for which fact we may all sorrow, yet for him I do not sorrow, whatever my regret may be. David Sheldrick was born in Africa, his father being one of those who went into East Africa with idealism, not with extractive intent. The original Tree Tops was one of the father's creations. David and I knew each other for over twenty years, in which time he and I once lived in camp together for three months in the Mara when it was less visited and accessible than now. He was the most civilised of men: I never heard him raise his voice nor belittle the people among whom he lived, even those who killed the creatures for which he lived. David loved the animals without demands on them. The care with which he reared and healed the young elephants which passed through his hands was beautiful to watch and inspiring, yet there was no trace of false sentiment. Mervyn Cowie chose David for the East Tsavo and the anti-poaching campaign to conserve the elephant herds, and Mervyn knew enough to leave David alone to manage the job. David was born to command and did, yet with self-effacement devoid of mock modesty. He was a gentle man of high courage. Perhaps David Sheldrick is part of the age-old tragedy of Africa, but for some of us still living his memory will survive a while. Our hearts go out to his wife who was so closely associated with his work'. 